\title{
Squamata, Iguania, Anolis punctatus Daudin, 1802 and Tropidurus torquatus (Wied, 1820): Distribution extension and new records for Ilha Grande, state of Rio de Janeiro, southeastern Brazil
}

\author{
Gisele R. Winck ${ }^{1 *}$, Davor Vrcibradic ${ }^{2}$, Felipe Bottona da Silva Telles ${ }^{1}$, Vitor Nelson T. Borges-Júnior ${ }^{1}$, \\ Monique Van Sluys ${ }^{1}$ and Carlos Frederico D. Rocha ${ }^{1}$ \\ 1 Universidade do Estado do Rio de Janeiro, Instituto de Biologia, Departamento de Ecologia. Rua São Francisco Xavier 524, sala 220, Maracanã \\ CEP 20550-011. Rio de Janeiro, RJ, Brasil. \\ 2 Universidade Federal do Estado do Rio de Janeiro, Instituto de Biociências, Departamento de Zoologia. Avenida Pasteur 458, sala 402, Urca. CEP \\ 20290-240. Rio de Janeiro, RJ, Brasil. \\ * Corresponding author. E-mail: gwinck@yahoo.com.br.
}

\begin{abstract}
The knowledge on the insular reptile fauna from Ilha Grande (state of Rio de Janeiro, Brazil) is mostly restricted to the results of surveys carried out within a limited area, considering the island's total area of 19,300 ha. Until now, the number of reptile species reported for Ilha Grande amounted to 25 (nine lizards and 16 snakes). Here we present the first records of two lizard species (Anolis punctatus and Tropidurus torquatus) for the island, raising the local reptile list to 27 species. The first one appears to be rare in the area, whereas the second species was found in a portion of the island that has not been previously surveyed for reptiles. Although the presence of T. torquatus in other insular environments may be related to anthropogenic introduction, we believe the population in Ilha Grande to be natural, considering the geological history of the island.
\end{abstract}

Ilha Grande is a large continental island $(19,300$ ha) located on the southern coast of the State of Rio de Janeiro (Municipality of Angra dos Reis), Brazil. Most of the island (ca. 90\%) is covered by Atlantic Forest sensu strictu (including primary and secondary forests), with the remaining being composed of marginal habitats such as rock outcrops, restingas, and mangroves (Alho et al. 2002). Recently, Rocha and Van Sluys (2006) compiled a first approximation to a list of reptile species for Ilha Grande based on data gathered by them and their students during an eight-year period (1995-2002). The list included 25 species (nine lizards and 16 snakes). In the present note we add two more reptile species to the aforementioned list, increasing to 27 the number of reptile species and to 11 the number of lizard species recorded for Ilha Grande. Additionally, we make some comments on the distribution of one of those species along the eastern Brazilian coast.

All lizards were collected during field expeditions related to projects conducted by the authors. The specimens were captured by hand or air-gun, euthanized through ether inhalation, fixed in $10 \%$ formalin solution, and kept in $70 \%$ alcohol solution. The specimens are housed at the reptile collection of the Museu Nacional, Rio de Janeiro (Anolis punctatus: MNRJ 18391; Tropidurus torquatus: MNRJ 18192-96).

In September 2004, an adult Anolis punctatus Daudin, 1802 was collected at the border of a stream on the trail that links the Vila dos Dois Rios village to the Caxadaço beach $\left(23^{\circ} 10^{\prime} 40.2^{\prime \prime}\right.$ S, $\left.44^{\circ} 11^{\prime} 10.7^{\prime \prime} \mathrm{W}\right)$ (Figure 1) by Vitor Nelson T. Borges-Júnior, under authorization number 17474-1 (IBAMA/ICMBio). On 18 and 19 March 2009 four specimens of Tropidurus torquatus (Wied, 1820) were collected at Lopes Mendes beach $\left(23^{\circ} 10^{\prime} 1.1^{\prime \prime}\right.$ S, $44^{\circ} 08^{\prime} 0.8^{\prime \prime}$
W) (Figure 1), by Gisele R. Winck, Camila Lacerda, and Débora G. Costa, under the authorizations of IBAMA (process number 15322-2) and INEA/PEIG (process number 033/2008).

The A. punctatus collected in 2004 was found inactive, at night, perching on a tree branch at over three meters above ground. Anolis punctatus is a forest-dwelling polychrotid lizard that has a wide distribution within cisandean South America. It is widespread in Amazonia and in the Brazilian

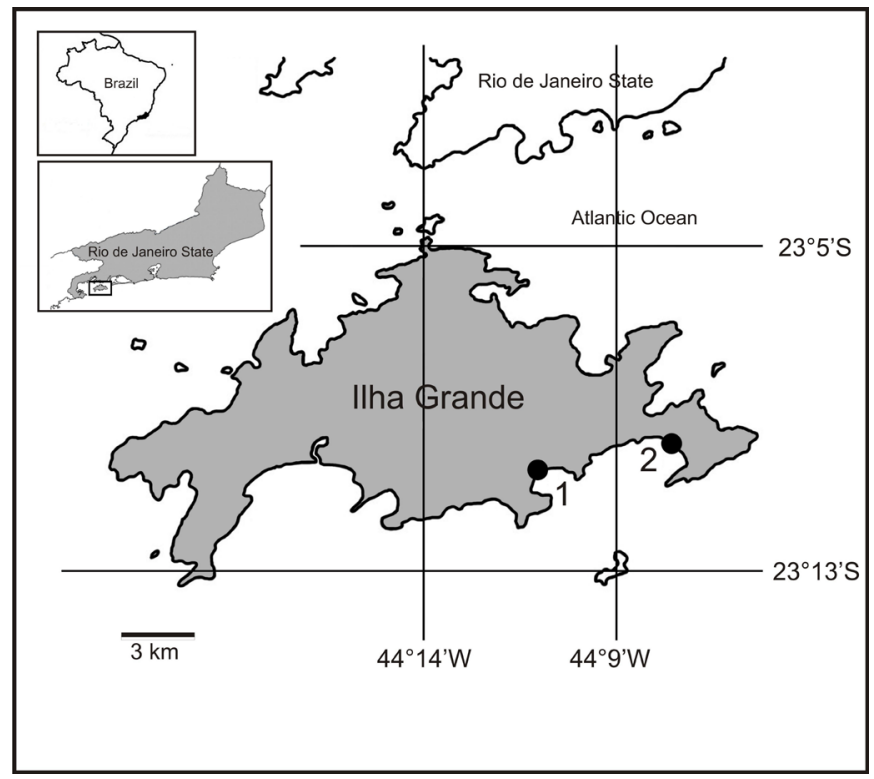

FIGURE 1. Location of Ilha Grande on the southern coast of the state of Rio de Janeiro, southeastern Brazil, with the localities from which the new records have been reported: 1 - Vila dos Dois Rios (new record for Anolis punctatus); 2 - Lopes Mendes beach (new record for Tropidurus torquatus). 
Atlantic Forest, where it ranges southwards to the region of Boracéia in São Paulo state (Ávila-Pires 1995). Although its presence in Ilha Grande is to be expected, as it lies within the species' distributional range, it has not been previously recorded there by Rocha and Van Sluys (2006). It is possible that the species is locally rare, and/or that its arboreal habits could make it not easily detectable, as it may often perch above the eye-level of human observers (Vitt et al. 2003).

The site where the Tropidurus torquatus specimens were found is an anthropically disturbed remnant of restinga habitat. In the past, part of the original vegetation has been removed for the establishment of a dirt runway for light aircrafts, or replaced by some exotic species (e.g., the 'almond tree' Terminalia catappa). Tropidurus torquatus is another wide-ranging South American species, occurring from the central Brazilian cerrados southwards to northern Argentina and eastwards to the eastern coast of Brazil, where it occurs mainly associated with open habitats (Rodrigues 1987). The species is usually abundant at restinga habitats (coastal sandy shrublands common along the eastern Brazilian coast), a component of the Atlantic Forest biome (Rocha 2000). Along the Brazilian coast, the species is known to occur from Guaibim, in the state of Bahia, to the Restinga da Marambaia, in the state of Rio de Janeiro (Rodrigues 1987; Carvalho et al. 2007). Recently, Sena et al. (2008) reported a population of T. torquatus from the municipality of Bertioga, in the state of São Paulo, some $215 \mathrm{~km}$ southwest of the Restinga da Marambaia, representing the southernmost and westernmost record of the species along the eastern Brazilian coast. The present record partially bridges the distribution gap between Bertioga and the Restinga da Marambaia, being ca. $20 \mathrm{~km}$ to the southwest of the latter locality. However, Sena et al. (2008) believe that the Bertioga population of T. torquatus represents a recent occupation as a result of local human-related habitat disturbances. However, we do not believe that this should be the case of the insular population from Ilha Grande, which is probably a natural one. Considering the geological history from Pleistocene, Ilha Grande became isolated from the mainland relatively recently, at 5100 years B.P., when the central canal and the Sepetiba and Ilha Grande bays were submerged as the sea level rose (see Gama et al. 2009). The Ilha Grande population of T. torquatus may thus represent a subset of a continental population that had been trapped by the sea level fluctuations. The fact that all other 26 reptile species reported for Ilha Grande (Rocha and Van Sluys 2006; present study) also occur on the mainland of Rio de Janeiro state reinforces this hypothesis. Other authors have argued that insular faunal communities of the southern Rio de Janeiro coast represent subsets of the continental biota (e.g. Oliveira 2002; Esberárd et al. 2006; Carvalho et al. 2007; Silva et al. 2008; Alves and Vecchi 2009). It is also worth noting that Ilha Grande is only ca. $2 \mathrm{~km}$ away from the mainland at its nearest point, which suggests that colonization by T. torquatus via transmarine dispersal is also a possibility. Natural populations of T. torquatus occur on the oceanic archipelago of Abrolhos (Rodrigues 1987), which lies some $70 \mathrm{~km}$ off the coast of Bahia state (NE Brazil), suggesting that this species may be a good transmarine colonizer. The T. torquatus population from Ilha Grande has gone unreported until now probably due to lack of collections, rather than actual previous absence from the area. Indeed, the list of Rocha and Van Sluys (2006) is based mainly on records from areas around the

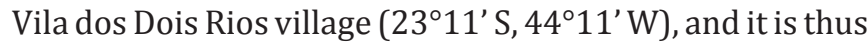
possible that $T$. torquatus may not occur in that particular region within the island.

ACKNOWLEDGMENTS: We are grateful to the IBAMA and the INEA (formerly IEF) for authorizing collection of specimens. Ronaldo Fernandes and Adriano L. Silveira confirmed the specific identity of the lizards. We also thank Débora G. Costa and Camila Lacerda for their assistance in fieldwork. We are grateful to the reviewers, for suggestions and comments. Fundação Carlos Chagas de Apoio à Pesquisa do Estado do Rio de Janeiro (FAPERJ) granted doctoral scholarship fund to GRW (process number E-26/100.769/2008), and support CFDR through Programa Cientistas do Nosso Estado (process number E-26/102.404/2009). The Conselho Nacional de Desenvolvimento Científico e Tecnológico (CNPq) also support CFDR (processes numbers 476684/2008-0 and 307653/2003-0).

\section{Literature Cited}

Alho, C.J.R., M. Schneider and L.A.Vasconcellos. 2002. Degree of threat to the biological diversity in the Ilha Grande State Park (RJ) and guidelines for conservation. Brazilian Journal of Biology 62(3): 375385.

Alves, M.A.S. and M.B. Vecchi. 2009. Birds, Ilha Grande, state of Rio de Janeiro, Southeastern Brazil. Check List 5(2): 300-313.

Ávila-Pires, T.C.S. 1995. Lizards of Brazilian Amazonia (Reptilia: Squamata). Zoologische Verhandelingen 299: 1-706.

Carvalho, A.L.G., A.F.B. Araújo and H.R. Silva. 2007. Lagartos da Marambaia, um remanescente insular de Restinga e Floresta Atlântica no Estado do Rio de Janeiro, Brasil. Biota Neotropica 7(2): 221-226.

Esbérard, C.E.L., T.J. Nogueira, J.L. Luz, G.G. Melo, R. Mangolin, N. Jucá, D.S.L. Raíces, M.C. Enrici and H.G. Bergallo. 2006. Morcegos da Ilha Grande, Angra dos Reis, RJ, Sudeste do Brasil. Revista Brasileira de Zoociências 8(2): 147-153.

Gama, S.V.G., L.G.A.E. Silva and C.M. Salgado. 2009. Geologia, relevo e solos; p. 21-61 In M. Bastos and C. H. Callado (org.). O Ambiente da Ilha Grande. Rio de Janeiro: UERJ/CEADS.

Oliveira, R.R. 2002. Ação antrópica e resultantes sobre a estrutura e composição da Mata Atlântica na Ilha Grande, RJ. Rodriguésia 53 (82): 33-58.

Rocha, C.F.D. 2000. Biogeografia de répteis de restingas: distribuição, ocorrência e endemismos; p. 99-116 In F.A. Esteves and L.D. Lacerda (ed.). Ecologia de Restingas e Lagoas Costeiras. Macaé: NUPEM/UFRJ.

Rocha, C.F.D. and M. Van Sluys. 2006. New records of reptiles from Ilha Grande Island in Rio de Janeiro State, Brazil. Herpetological Review 37(1): 112-114.

Rodrigues, M.T. 1987. Sistemática, ecologia e zoogeografia dos Tropidurus do grupo torquatus ao sul do Rio Amazonas (Sauria, Iguanidae). Arquivos de Zoologia, São Paulo 31(3): 105-230.

Sena, M.A., J. Cassimiro, C.J. David, J.G. Silva and M.T. Rodrigues. 2008. Geographic distribution. Tropidurus torquatus. Herpetological Review 39(3): 369.

Silva, H.R., A.L.G. Carvalho and G.B. Bittencourt-Silva. 2008. Frogs of Marambaia: a naturally isolated Restinga and Atlantic Forest remnant of southeastern Brazil . Biota Neotropica 8(4): 167-174.

Vitt, L.J., T.C.S. Ávila-Pires, M.C. Espósito, S.S. Sartorius and P.A. Zani. 2003. Sharing amazonian rain-forest trees: ecology of Anolis punctatus and Anolis transversalis (Squamata: Polychrotidae). Journal of Herpetology 37(2): 276-285.

RECEIVED: September 2009

LAST REVISED: December 2010

ACCEPTED: April 2011

Published ONLINE: May 2011

EDITORIAL RESPONSIBILITY: Alexandro Marques Tozetti 